\title{
Membangun Kemandirian Ekonomi Desa melalui Peningkatan Daya Saing Potensi Kekayaan Alam Perdesaan
}

\author{
Lina Krisnawati
}

Akuntansi, Universitas Peradaban, Indonesia

Adi Susanto

Manajemen, Universitas Peradaban, Indonesia

Sutarmin

Manajemen, Universitas Peradaban, Indonesia

Korespondensi penulis: linakrisnawati76@yahoo.com

\begin{abstract}
As many as $83 \%$ of Indonesia's territory is rural. Each region has natural resource potential. However, it is still rarely managed properly. If managed properly, it has the potential to create economic independence from each of these villages. Currently, Indonesia has a total of 70,611 villages. Of the total villages, $49.9 \%$ or 32,379 of them are underdeveloped villages. In Central Java, currently there are 40.5\% of disadvantaged villages or 3,467 villages out of 8,564 villages. Village empowerment provides great benefits for the welfare of the lives of rural communities. The concept of OVOP (one village one product) is one of the concepts or models of village selfsufficiency. Research is needed to explore the potential of a village and how its development planning strategy. In the process of development, villages are empowered to be economically independent and their people's welfare will increase significantly. The study aims to identify resources, strength, weakness, opportunity, and threat factors, analyze the position of competitiveness, and formulate strategies to realize the Sunyalangu as an economically self-sufficient village. Data collection methods in this study used Secondary Data Review (SDR), Direct Observation, Semi-Structured Interview (SSI), and Focus Group Discussion (FGD), while the sample of the informants in this study were determined purposively by certain criteria or guidelines.
\end{abstract}

Keywords: Economically self-sufficient village, OVOP, advantaged villages, brown sugar, natural resources, competitiveness.

\begin{abstract}
Abstrak. Sebanyak 83\% wilayah Indonesia adalah perdesaan. Setiap daerah memiliki potensi sumber daya alam. Namun, potensi tersebut masih jarang dikelola dengan baik. Jika potensi daerah dikelola dengan baik, daerah tersebut berpotensi menciptakan kemandirian ekonomi pada masing-masing desa. Saat ini, Indonesia memiliki 70.611 desa. Dari total desa tersebut, 49,9\% atau 32.379 di antaranya adalah desa tertinggal. Di Jawa Tengah, saat ini masih ada 40,5\% desa tertinggal atau 3.467 desa dari jumlah keseluruhan 8.564 desa. Upaya pemberdayaan desa akan memberikan manfaat besar bagi kesejahteraan kehidupan masyarakat di perdesaan. Konsep OVOP (satu desa satu
\end{abstract}


produk) adalah salah satu konsep atau model swasembada desa. Penelitian tentang desa diperlukan untuk mengeksplorasi potensi desa dan bagaimana strategi perencanaan pembangunannya. Dalam proses tersebut, desa diberdayakan untuk mandiri secara ekonomi dan kesejahteraan rakyatnya akan meningkat secara signifikan. Penelitian ini bertujuan untuk mengidentifikasi faktor sumber daya, kekuatan, kelemahan, peluang, dan ancaman, menganalisis posisi daya saing, dan merumuskan strategi untuk mewujudkan Desa Sunyalangu sebagai desa mandiri secara ekonomi. Metode pengumpulan data terdiri atas Secondary Data Review (SDR), Pengamatan Langsung, Wawancara Semi-Terstruktur (SSI), dan Diskusi Kelompok Terfokus (FGD), sedangkan sampel informan dalam penelitian ini ditentukan secara purposive dengan kriteria atau pedoman tertentu.

Kata kunci: Desa mandiri secara ekonomi, OVOP, desa yang diuntungkan, gula semut, sumber daya alam, daya saing.

Article Info:

Received: October 19, $2018 \quad$ Accepted: March 5, 2019

Available Online: April 11, 2019 DOI: http://dx.doi.org/10.30588/jmp.v8i2.396

\section{LATAR BELAKANG}

Kecukupan penghasilan dan peluang lapangan kerja yang tinggi dapat dijamin dari potensi gula kelapa. Potensi ekonomi maupun potensi sosial tanaman kelapa merupakam suatu faktor yang menarik untuk dikaji secara lebih mendalam karena berbagai besaran sebagaimana telah disebut di atas. Hasil nira kelapa tidak hanya dibuat untuk menjadi gula cetak saja, tetapi bisa juga diolah menjadi gula kristal yang saat ini sudah mampu diekspor ke luar negeri. Pemerintah dan perguruan tinggi harus dapat bersinergi untuk memikirkan bagaimana cara memunculkan klaster-klaster kemandirian ekonomi baru, tidak hanya di perkotaan, tetapi juga di perdesaan.

Potensi-potensi yang ada di masing-masing desa seharusnya dapat digali dan dikembangkan menjadi sumber daya ekonomi. Hal tersebut bukan hanya bersifat potensi saja, tetapi perlu upaya pemberdayaan hingga mampu memberikan manfaat yang sebesar-besarnya bagi kesejahteraan kehidupan masyarakat perdesaan. Konsep OVOP (one village one product) merupakan salah satu konsep atau model kemandirian desa. Pengembangan potensi desa perlu dilakukan melalui inovasi berbasis pada kearifan lokal. Potensi sumber daya dan keunikannya merupakan salah satu upaya untuk mendorong perekonomian lokal menuju desa mandiri. Desa mandiri merupakan desa yang mampu mendayagunakan sumber daya dengan cara yang berbeda.

Menurut data Kementerian Desa dan Pembangunan Daerah Tertinggal, saat ini Indonesia memiliki 70.611 desa. Dari jumlah desa tersebut 32.379 di antaranya berstatus desa tertinggal atau sebesar 49,9\%. Provinsi Papua merupakan provinsi yang menempati peringkat utama dalam status desa tertinggal. Dari 2.179 desa di Papua, 1.795 desa masih hidup dalam keterbelakangan. Saat ini, Provinsi Jawa Tengah memiliki desa tertinggal sebanyak 40,5\% atau 3.467 desa tertinggal dari 8.564 desa yang ada. Sejalan dengan program desa inovasi dan kemandirian desa secara ekonomi, Rapat Kerja Nasional Kementerian Riset, Teknologi, dan Pendidikan Tinggi (Kemen- 
ristekdikti) mengangkat tema Peningkatan Daya Saing Bangsa Melalui Peningkatan Mutu Pendidikan Tinggi dan Inovasi (Kemenristekdikti, 2015). Pusat Ilmu Pengetahuan dan Teknologi (Iptek) diharapkan mampu meningkatkan daya saing industri nasional. Pusat Iptek (science and techno-park) yang mulai dikembangkan di sejumlah kota di Indonesia menjadi ajang hilirisasi hasil riset iptek. Interaksi dan kolaborasi lembaga riset, pendidikan, dan industri dapat terjadi di kawasan tersebut di dalam satu sistem dengan menggunakan sumber daya lokal. Pada puncak Hari Nusantara ke-14 tahun 2014, pemerintah mendeklarasikan 1000 Desa Inovasi Nelayan yang akan dibangun dalam 1000 hari bersama Kemenristekdikti.

Kabupaten Banyumas memiliki wacana untuk mengembangkan desa mandiri. Namun, sampai saat ini Pemerintah Kabupaten Banyumas belum memutuskan desa mana yang akan dipilih di antara 301 desa yang ada untuk dikembangkan. Pemerintah kabupaten perlu memfokuskan pada satu desa terlebih dahulu sebagai percontohan atau rujukan desa-desa lain yang akan bertransformasi menjadi desa mandiri. Hal ini dilakukan dalam rangka upaya pengembangan potensi ekonomi desa. Sunyalangu merupakan desa yang berada di Kecamatan Karanglewas. Letak desa Sungalayu yang berada di tengah-tengah dua kecamatan yang ada di Kabupaten Banyumas, yaitu antara Kecamatan Kedungbanteng dan Kecamatan Cilongok. Meskipun agak terpencil, tetapi desa Sungalayu memiliki potensi menghasilkan nira yang berkualitas tinggi dan bahkan menjadi sentra pembuatan gula cetak dan gula semut yang tersebar di beberapa dusunnya.

Desa Sunyalangu merupakan penghasil gula kristal yang diekspor ke luar negeri. Sebagian besar warga Desa Sunyalangu berprofesi sebagai penyadap nira dan sekaligus pembuat gula cetak maupun gula kristal. Karena letaknya yang berdekatan dengan hutan negara, hal itu memungkinkan penghasilan warga dari pengolahan nira di Desa Sunyalangu cukup melimpah. Posisi Desa Sunyalangu cukup jauh dari permukiman kota, sehingga warga Desa Sunyalangu terpacu untuk mampu memanfaatkan sumber daya alam yang tersedia secara optimal.

Desa Sunyalangu telah memiliki siklus perdagangan yang akan menggerakkan roda perekonomian desa. Jika sinergi dengan lembaga yang memiliki kompetensi dalam bidang ilmu pengetahuan dan teknologi dilakukan, program desa inovasi akan dapat terwujud dengan lebih mudah. Dalam hal ini, sentuhan ilmu pengetahuan dan teknologi diperlukan dalam bentuk ketrampilan manajemen rantai pasok, pengendalian kualitas produk, perbaikan tata cara budi daya, dan pengenalan teknologi yang lebih maju dan tepat guna. Desa inovatif merupakan sebuah konsep baru, sehingga belum banyak penelitian-penelitian yang dapat dirujuk untuk penelitian ini. Namun, desa lain dapat mengambil contoh Desa Sunyalangu sebagai desa inovasi. Kabupaten Banyumas memiliki sebuah desa yang terletak di Kecamatan Karanglewas, yaitu Desa Sunyalangu yang memiliki potensi sebagai desa penghasil nira untuk diupayakan mampu menjadi desa mandiri secara ekonomi di Kabupaten Banyumas, Jawa Tengah.

Tujuan umum penelitian ini adalah merumuskan konsep atau formula untuk mengembangkan suatu desa mandiri ekonomi yang ada di Banyumas, sedangkan tujuan khusus dalam penelitian ini adalah mengidentifikasi: (1) sumber daya yang dapat membantu kemandirian ekonomi, (2) faktor kekuatan yang mendukung Desa Sunyalangu menjadi desa mandiri ekonomi, (3) faktor kelemahan yang menghambat Desa Sunyalangu menjadi desa mandiri ekonomi, (4) kesempatan yang bisa dimanfaatkan 
Desa Sunyalangu menjadi desa mandiri ekonomi, dan (5) ancaman apa saja yang dapat mengganggu Desa Sunyalangu menjadi desa mandiri ekonomi.

\section{KAJIAN TEORITIS}

\section{Desa}

Undang-Undang nomor 6 tahun 2014 pasal 1 ayat 1 menyebutkan bahwa desa adalah desa dan desa adat atau yang disebut dengan nama lain, yang selanjutnya disebut desa, adalah kesatuan masyarakat hukum yang memiliki batas wilayah yang berwenang untuk mengatur dan mengurus urusan pemerintahan, kepentingan masyarakat setempat berdasarkan prakarsa masyarakat, hak asal usul, dan/atau hak tradisional yang diakui dan dihormati dalam sistem pemerintahan Negara Kesatuan Republik Indonesia. Pada tahun 2013, 72.944 wilayah administrasi desa dan 8.309 wilayah administrasi kelurahan tercatat dalam data di Kementerian Dalam Negeri berupa buku induk kode dan data wilayah administrasi pemerintahan per provinsi, kabupaten/kota, dan kecamatan seluruh Indonesia. Jumlah administrasi kelurahan terbanyak berada di Provinsi Jawa Tengah, yaitu 8.577 unit desa/kelurahan, dan paling sedikit berada di Provinsi DKI Jakarta sebanyak 267 unit dari jumlah total wilayah administrasi setingkat desa dan kelurahan sebanyak 81.253 unit.

\section{Pengembangan Lokal}

Becattini et al. (2003) menyatakan bahwa pengembangan lokal merupakan integrasi pembangunan yang memadukan dimensi ekonomi dengan dimensi lainnya seperti, sosial, budaya, dan institusi dengan penekanan pada konteks spasial yang bersifat lokal. Pengembangan yang dimaksud tersebut merupakan proses yang ada di masyarakat, pemerintah, para pelaku usaha, dan sektor non-pemerintah lainnya bekerja bersama-sama untuk menciptakan kondisi yang lebih baik pada pertumbuhan ekonomi maupun kesejahteraan masyarakat. Kerangka kajian keberlangsungan hidup manusia tidak habis-habisnya membahas salah satu fenomena, yaitu pembangunan. Pembangunan sebagai salah satu fenomena yang melekat dalam salah satu ciri kehidupan manusia kerap mengalami perubahan mengikuti berbagai dimensi yang ada. Konteks kajian suatu perubahan biasanya dilekatkan dengan konsep pembangunan yang diartikan sebagai bentuk perubahan terencana, perubahan yang mempunyai bentuk lebih baik daripada keadaan sebelumnya dan diharapkan oleh setiap orang atau kelompok tertentu. Perencanaan diperlukan untuk mewujudkan harapan tersebut.

Tujuan pengembangan lokal adalah peningkatan kualitas hidup seluruh masyarakat pada suatu daerah tertentu dengan memanfaatkan sumber daya yang ada dari dalam masyarakat itu sendiri. Dewasa ini, pengembangan lokal telah mengalami berbagai kemajuan di dalamnya, salah satunya adalah inovasi. Inovasi merupakan sebuah proses yang heterogen dan mencakup aliran atau mobilisasi sumber daya internal dan eksternal yang melibatkan tiga aspek penting, yaitu: aktor, sumber daya, dan aktifitasnya (Oerlemans et al., 2001). Ada pun aktor-aktor yang ada di dalamnya akan saling berinteraksi dan mempengaruhi inovasi tersebut, sehingga akan meningkatkan produktifitas desa mandiri. Produktifitas tersebut akan mengakibatkan produk desa mandiri akan mampu bersaing di pasar lokal maupun global. Dengan meningkatnya aliran produk dari desa mandiri, secara otomatis hal itu akan meningkatkan juga pendapatan para pelaku usaha di desa. Oleh karena itu, keberadaan 
inovasi sangat penting dalam memberikan keuntungan/profit, baik untuk klaster maupun pelaku usaha di desa mandiri.

\section{Desa Mandiri}

Beberapa kebijakan strategis dalam sebuah program, yaitu: (1) percepatan integrasi pasar tenaga kerja pertanian dan non-pertanian dengan dukungan perbaikan pasar finansial; (2) fokus pada pembangunan pertanian dan perdesaan tanpa mengabaikan pertumbuhan sektor perkotaan; (3) perbaikan kapasitas dan akses ekonomi penduduk miskin melalui investasi perdesaan dan migrasi tenaga kerja; (4) perbaikan inovasi teknologi rantai pasok; dan (5) investasi infrastruktur dan sistem komunikasi untuk mengurangi disparitas merupakan saran-saran percepatan transformasi struktural dan pertumbuhan inklusif pembangunan pertanian dan perdesaan (Timmer, 2006; Henderson, 2007; IFPRI \& ADB, 2007). Menempatkan masyarakat sebagai subyek pemberdayaan dalam rangka mengenali permasalahan dan ikut dalam perencanaan program akan menghasilkan kemandirian yang tinggi (Mubyarto, 1984; Sajogyo, 1982).

\section{Participatory Rural Appraisal (PRA)}

Menurut Chamber (1996), sekelompok pendekatan atau metode yang memungkinkan masyarakat desa untuk saling berbagi, meningkatkan, dan menganalisis pengetahuan mereka tentang kondisi dan kehidupan desa, serta membuat rencana dan tindakan nyata disebut participatory rural appraisal (PRA) atau penilaian/pengkajian/ penelitian keadaan desa secara partisipatif. Penggunaan paradigma pembangunan berkelanjutan sebagai landasan pembangunan di negara-negara sedang berkembang membuat metode dan pendekatan ini semakin meluas dan diakui kegunaannya. Manusia ditempatkan sebagai inti di dalam proses pembangunan berbasis paradigma pembangunan berkelanjutan dan tidak hanya sebagai penonton, tetapi mereka dapat secara aktif ikut serta di dalam proses perencanaan, pelaksanaan, pengawasan, dan menikmati hasil-hasil pembangunan. Metode dan pendekatan yang partisipatif adalah metode dan pendekatan yang sesuai dengan tuntutan paradigma pembangunan berkelanjutan.

Metode Pemahaman Cepat Kondisi Perdesaan (PCKP) atau Rapid Rural Appraisal (RPA) menyebar pada tahun 1980an dan dikembangkan dengan cepat dalam bentuk metode PRA pada tahun 1990an. Keduanya saling berhubungan erat dan masing-masing mempunyai kelebihan maupun kekurangannya, tetapi keduanya dapat saling melengkapi. Dalam perkembangannya, metode PRA banyak digunakan dalam proses pelaksanaan program pembangunan partisipatif, baik pada tahap perencanaan, pelaksanaan, maupun pengawasannya.

\section{Penelitian Terdahulu}

Metode PRA dipandang telah memiliki teknik yang dijabarkan cukup operasional dengan konsep keterlibatan masyarakat yang sangat diperlukan dalam seluruh kegiatan. Beberapa prinsip dasar yang harus dipenuhi dalam metode PRA antara lain: saling belajar dan berbagi pengalaman, keterlibatan semua anggota kelompok dan informasi, orang luar sebagai fasilitator, konsep triangulasi, optimalisasi hasil, orientasi praktis, dan keberlanjutan program (Rochdyanto \& Saiful, 2000). Cita-cita untuk menjadikan masyarakat sebagai peneliti, perencana, dan pelaksana pembangunan dan bukan sekedar obyek pembangunan merupakan salah satu pendekatan dalam penerapan PRA. Nilai 
praktis untuk pengembangan program merupakan penekanan aspek penelitian dan bukan pada validitas data yang diperoleh.

\section{Analisis SWOT (Strengths, Weaknesses, Opportunities, Threats)}

Menurut Kurtz (2008:45), SWOT (analisis kekuatan, kelemahan, peluang, dan ancaman) adalah suatu alat perencanaan strategik yang penting untuk membantu perencana dalam membandingkan kekuatan dan kelemahan internal organisasi dengan peluang dan ancaman eksternalnya. Menurut Pearce dan Robinson (2003:134), analisis SWOT perlu dilakukan untuk mencocokkan kesesuaian ( $f i t)$ antara sumber daya internal dan situasi eksternal perusahaan. Menganalisis lingkungan internal dan eksternal merupakan hal penting dalam proses perencanaan strategi (Bradford et al., 2007:142). Penggolongan faktor-faktor lingkungan internal di dalam perusahaan adalah Strength (S) dan Weaknesses (W), sedangkan Opportunities (O) atau Threats (T) diklasifikasikan sebagai lingkungan eksternal perusahaan. Analisis lingkungan ini disebut sebagai analisis SWOT.

Penerapan analisis SWOT cukup sederhana dan dapat dijadikan sebagai alat bantu untuk memperbesar kapabilitas, mengetahui ketidakefisienan sumber daya perusahaan, dan kesempatan pasar serta ancaman eksternal untuk masa depan agar lebih baik (Thompson, 2008:97). Analisis SWOT merupakan metode perencanaan strategik yang berfungsi untuk mengevaluasi kekuatan, kelemahan, peluang, dan ancaman suatu perusahaan (David, 1997:134). Penentuan tujuan spesifik dari spekulasi bisnis dan identifikasi faktor internal dan eksternal yang mendukung maupun yang tidak dalam mencapai tujuan akan dilibatkan dalam proses ini.

\section{METODE PENELITIAN}

Prosedur penelitian ini menghasilkan data diskriptif, sehingga jenis peneltian ini adalah penelitian kualitatif. Peneliti membuat suatu gambaran kompleks, meneliti katakata, laporan terinci dari pandangan responden, dan melakukan analisis pada situasi yang alami. Data kualitatif digunakan untuk menjawab pertanyaan penelitian yang diajukan. Pengembangan model desa inovatif sangat kompleks dan fenomenanya tidak bisa dilepaskan dari aspek-aspek psikologi sosial yang bersifat soft, seperti aspek kepemimpinan, modal sosial, kewirausahaan. Namun, aspek yang bersifat hard, seperti potensi desa dan aktivitas-aktivitas ekonomi yang ada di desa pun juga dianalisis.

Penelitian dilaksanakan mulai bulan Juni sampai dengan Oktober tahun 2018. Lokasi penelitian difokuskan di Desa Sunyalangu Kecamatan Karanglewas Kabupaten Banyumas. Data sekunder dan data primer digunakan dalam penelitian ini. Data primer diperoleh langsung dari responden. Responden dalam penelitian ini, antara lain partisipan penelitian meliputi Kepala Desa Sunyalangu, aparatur desa, Badan Permusyawaratan Desa (BPD), Badan Perencanaan Pembangunan Daerah (Bappeda), Badan Pemberdayaan Masyarakat, dan instansi terkait lainnya. Metode pengumpulan data yang digunakan dalam penelitian ini adalah: (1) Secondary Data Review (SDR), (2) Direct Observation, (3) Semi-Structured Interviewing (SSI), dan (4) Focus Group Discussion (FGD). Partisipan penelitian ditentukan secara purposive.

Semi-Structured Interviewing (SSI) merupakan wawancara semi terstruktur yang menggunakan panduan pertanyaan sistematis, tetapi masih mungkin untuk berkembang selama interview dilaksanakan. Data diperoleh secara langsung dari responden yaitu 
partisipan penelitian yang meliputi Kepala Desa Sunyalangu, aparatur desa, dan Badan Permusyawaratan Desa (BPD), Badan Perencanaan Pembangunan Daerah (Bappeda), Badan Pemberdayaan Masyarakat, dan instansi terkait lainnya. Focus Group Discussion (FGD), yaitu diskusi yang melibatkan beberapa orang untuk membicarakan hal-hal bersifat khusus secara mendalam. Tujuan FGD adalah mendapatkan gambaran terhadap suatu masalah tertentu secara lebih rinci. FGD juga dilakukan terutama untuk menentukan faktor dominan dan bobot dalam posisi daya saing dan alternatif strategi yang terbaik.

Ketekunan dimaksudkan sebagai uji validitas internal (uji kredibilitas) dilakukan melalui peningkatan ketekunan, penggunaan referensi, diskusi teman sejawat (membercheck), dan triangulasi dilakukan dalam rangka uji validitas internal (uji kredibilitas). Pengamatan yang lebih cermat di lapangan dan mengecek kembali data yang disajikan apakah sudah tepat dan logis atau belum dilakukan dalam rangka peningkatan ketekunan. Uji validitas menggunakan bahan referensi berupa rekaman suara, video, dan foto dilakukan untuk meningkatkan ketekunan. Aktifitas membercheck melalui pertanyaan ulang kepada pemberi informasi tentang apakah data yang disampaikan sudah benar sesuai dengan fakta dan kondisi. Pengecekan data dengan cara mengecek sumber merupakan triangulasi dalam penelitian ini. Audit terhadap keseluruhan proses penelitian dilakukan untuk mendapatkan reliabilitas dalam penelitian ini.

Setelah dilakukan pengumpulan, data dipilah dan dikelompokkan dengan melakukan identifikasi sumber daya, faktor internal, dan faktor eksternal. Formulasi strategi dirumuskan untuk mewujudkan desa mandiri melalui pendekatan dengan menggunakan analisis SWOT (Strengths-Weaknesses-Opportunities-Threats). Sebelum dilakukan analisis SWOT, peneliti juga melakukan analisis External Factor Evaluation (EFE), Internal Factor Evaluation (IFE), dan Internal-External Matrix (IE Matrix).

\section{HASIL PENELITIAN DAN PEMBAHASAN}

\section{Kondisi Desa Sunyalangu}

Desa Sunyalangu merupakan salah satu desa di Kecamatan Karanglewas Kabupaten Banyumas. Dari Kecamatan Karanglewas berjarak kurang lebih $10 \mathrm{~km}$. Pada tahun 2016, Desa Sunyalangu memiliki penduduk sebanyak 5.384 jiwa dengan komposisi laki-laki sebanyak 3.250 jiwa dan perempuan sebanyak 2.981 jiwa dan terdiri atas 1.422 Kepala Keluarga (KK). Tingkat pendidikan rata-rata penduduk di Desa Sunyalangu tergolong sedang, karena terbatasnya fasilitas pendidikan, yaitu: Taman Kanak-kanak (TK), PAUD (Pendidikan Anak Usia Dini), tiga unit Sekolah Dasar (SD), satu unit Madrasah Ibtidaiyah (MI), dan satu unit Sekolah Menengah Tingkat Pertama (SMP). Berdasarkan pekerjaan atau profesi, mayoritas penduduknya bekerja sebagai petani, buruh tani, dan penderes kelapa, sehingga pola kepemilikan lahan sangat berkaitan erat dengan mata pencahariannya.

\section{Sumber daya alam di Desa Sunyalangu}

Berdasarkan observasi lapangan, wawancara kepada aparat desa, dan beberapa anggota masyarakat menunjukkan bahwa hasil alam utama yang ada di Desa Sunyalangu adalah padi dan jagung. Hasil alam ini sekaligus mengarahkan mata pencaharian utama dari masyarakat Desa Sunyalangu. Pada musim penghujan, 
masyarakat menanam padi, sedangkan pada akhir musim penghujan mereka menanam jagung.

\section{Tolak Ukur (Benchmarking)}

Sesuai sifat penelitian ini, proses benchmarking penelitian ini dilakukan secara kualitatif. Selain karena cakupan yang tidak sampai dalam kegiatan analisis ini, hasil identifikasi faktor internal dan eksternal sangat sulit dilakukan. Faktor internal berupa kekuatan, maka dalam hal ini diasumsikan sebagai kondisi atau aktivitas yang lebih tinggi dari desa lain, sehingga desa Sunyalangu dianggap lebih tinggi dari desa lain yang dianggap sebagai benchmarknya. Begitu pula sebaliknya jika berupa kelemahan, maka diasumsikan Desa Sunyalangu berada di bawah rata-rata desa yang dipakai sebagai benchmark. Desa yang digunakan sebagai benchmark tersebut adalah Desa Sokawera, Kecamatan Cilongok. Desa Sokawera terletak di sebelah selatan Desa Babakan, Kecamatan Karanglewas, dan di sebelah timur Desa Baseh, Kecamatan Kedungbanteng.

\section{Faktor Internal}

Ada beberapa faktor internal (kekuatan dan kelemahan) yang mempengaruhi posisi daya saing Desa Sunyalangu sebagai desa inovatif dalam bidang budi daya dan produksi gula kelapa di Kabupaten Banyumas, yaitu:

\section{Kekuatan (Strength)}

\section{Keunggulan komparatif area budi daya dan pengolahan gula kelapa}

Desa Sunyalangu memiliki teknologi yang terbarukan. Beberapa pengepul memiliki alat pengolahan yang tidak dimiliki oleh desa-desa lain, yaitu alat pengovenan untuk memproduksi gula kristal. Teknologi ini banyak digunakan oleh beberapa pengepul untuk memberikan nilai tambah signifikan, sehingga kualitas gula kristal yang dihasilkan dapat menembus pasar ekspor.

\section{Tanaman kelapa banyak tumbuh di sekitar pekarangan}

Kondisi iklim dan cuaca kadang tidak menentu. Pada saat terjadi musim penghujan, beberapa daerah umumnya tidak dapat melakukan proses produksi pembuatan gula kelapa. Hal ini disebabkan karena tidak tersedia bahan baku di rumahnya. Selain banyaknya tanaman kelapa yang tumbuh di perkebunan, pohon kelapa juga banyak tumbuh di sekitar pekarangan belakang rumah warga, sehingga para penderes kelapa mudah untuk menghasilkan nira setiap harinya.

\section{Kemampuan dasar budi daya tanaman kelapa}

Desa Sunyalangu memiliki keunggulan komparatif berupa potensi tanaman nilam dan cengkeh. Secara tidak langsung, warga Desa Sunyalangu telah memiliki pengetahuan dasar dalam budi daya tanaman kelapa.

\section{Kemampuan dasar pengolahan gula cetak dan gula kristal}

Sebagian masyarakat Desa Sunyalangu mempunyai alat memasak gula kelapa berupa tungku, wajan, alat penyaringan, dan alat pendukung lain untuk proses produksi gula cetak maupun gula kristal. Secara tidak langsung, sebagian masyarakatnya telah memiliki kemampuan teknologi sederhana pemrosesan gula kelapa. 


\section{Kualitas sumber daya manusia (SDM) budi daya dan pengolahan}

Budi daya tanaman kelapa di Desa Sunyalangu dilakukan secara sederhana, tidak ada perawatan secara khusus untuk tanaman kelapa. Perawatan pohon kelapa hanya memerlukan pembersihan manggar agar nira yang dihasilkan lebih bersih. Meski pengolahan secara sederhana, gula kelapa yang dihasilkan tergolong memiliki kualitas yang baik. Masyarakat sangat memperhatikan proses pengolahan gula kelapa yang dihasilkan berupa gula organik tanpa adanya campuran bahan kimia apa pun. Secara khusus, petani gula kelapa sangat memperhatikan kebersihan dalam pemrosesan gula kristal, sehingga produk gula semut yang ada di Desa Sunyalangu mampu menembus pasar ekspor. Selain itu, petani dan pengepul gula kelapa di Desa Sunyalangu telah mendapatkan pelatihan dan kunjungan dari perusahaanperusahaan untuk meningkatkan kemampuan petani menghasilkan gula kelapa dan gula kristal yang bernilai jual tinggi.

\section{Infrastruktur transportasi cukup memadai}

Desa Sunyalangu berada di dalam wilayah perbukitan dengan infrastruktur jalan yang sudah cukup memadai. Kondisi ini memudahkan para pelaku usaha gula kelapa untuk melakukan aktifitas baik di dalam maupun luar desa.

\section{Memiliki sistem nilai rantai pasok}

Secara tidak langsung, potensi alam yang beraneka ragam dan cukup melimpah tersebut, serta keberadaan pabrik (Usaha Kecil Menengah atau UKM) pengolahan gula kelapa di desa, maka terbentuklah suatu mata rantai pasok dari bahan baku menjadi produk.

\section{Kelemahan (Weakness)}

\section{Manajemen sangat Sederhana}

Dengan kualitas SDM yang terbatas, apa yang dilakukan oleh masyarakat Desa Sunyalangu merupakan usaha terbaik menurut anggapan mereka. Sesungguhnya, hal tersebut hanyalah persepsi mereka karena belum mengenal dunia luar yang lebih luas. Begitu pula dalam hal manajemen usahanya, mereka banyak yang mencampuradukkan dengan kebutuhan hidup keluarganya. Demikian pula yang terjadi pada usaha UKM pengolahan gula kelapa. Kegiatan usaha ini tidak dilakukan pencatatan, sehingga tidak diketahui setiap luasan lahan menghasilkan berapa banyak bahan baku, berapa bahan baku masuk setiap proses produksi, berapa lama waktu untuk satu kali proses produksi, berapa banyak gula yang dihasilkan, dan berapa untung rugi setiap proses yang dilakukan.

\section{Tidak ada pengendalian Kualitas}

Di Desa Sunyalangu, proses produksi pembuatan gula kelapa ini hampir tidak ada pengendalian kualitas. Meskipun petani memperhatikan proses pengolahan untuk menghasilkan gula kelapa yang berkualitas baik, tetapi pengendalian kualitas belum dilaksanakan secara maksimal. Produk yang mereka hasilkan langsung dikumpulkan dan dikirimkan ke pengepul. 


\section{Teknologi pendukung sangat sederhana}

Sebagian masyarakat Desa Sunyalangu sudah mampu menghasilkan produk gula kelapa, baik gula cetak maupun gula kristal. Namun, sebagian besar teknologi yang digunakan masih sangat sederhana.

\section{Produktifitas dan efisiensi proses produksi rendah}

Alat produksi pembuatan gula kelapa yang ada di Desa Sunyalangu memiliki produktifitas yang rendah. Dalam satu hari, pelaku usaha hanya mampu melakukan satu kali proses produksi. Leadtime proses cukup panjang, yaitu rata-rata 3-5 jam untuk gula cetak dan 4-6 jam untuk gula kristal. Pengaturan untuk proses berikutnya tidak ada.

\section{Takut Bermitra dengan pihak lain}

Beberapa pemilik UKM gula kelapa dan gula kristal sangat takut apabila diajak bermitra dan dikembangkan lebih lanjut. Ketakutan tersebut di antaranya adalah takut terhadap proses perijinan yang bermacam-macam dan masalah pajak.

Setelah faktor-faktor kekuatan (strength) dan kelemahan (weakness) dapat diidentifikasi, selanjutnya penentuan bobot setiap faktor dilakukan. Pemberian bobot dilakukan dengan angka dari 0,0 hingga 1,0 sesuai dengan besar kecilnya pengaruh atau penting tidaknya faktor. Bobot 0,0 diberikan kepada faktor yang tidak penting dan 1,0 diberikan kepada faktor yang sangat penting. Faktor yang dianggap memiliki pengaruh paling besar akan diberikan bobot paling tinggi. Berdasarkan hasil analisis SWOT ini, skor bobot total sebesar 2,667 menunjukkan bahwa Desa Sunyalangu memiliki posisi internal yang cukup kuat, karena di atas rata-rata desa lain (Tabel 1 dan 2).

Tabel 1. Perbandingan Berpasangan Faktor Internal

\begin{tabular}{ccccccccccrrrrrr}
\hline No* & 1 & $\mathbf{2}$ & $\mathbf{3}$ & $\mathbf{4}$ & $\mathbf{5}$ & $\mathbf{6}$ & $\mathbf{7}$ & $\mathbf{8}$ & $\mathbf{9}$ & $\mathbf{1 0}$ & $\mathbf{1 1}$ & $\mathbf{1 2}$ & $\mathbf{1 3}$ & Jumlah & Bobot \\
\hline 1 & & 2 & 1 & 4 & 5 & 1 & 1 & 1 & 1 & 1 & 1 & 12 & 1 & 8 & 0,103 \\
2 & 2 & & 2 & 2 & 5 & 2 & 2 & 2 & 2 & 2 & 11 & 2 & 2 & 10 & 0,128 \\
3 & 1 & 2 & & 4 & 5 & 3 & 7 & 8 & 3 & 3 & 3 & 12 & 13 & 4 & 0,051 \\
4 & 4 & 2 & 4 & & 5 & 6 & 7 & 8 & 4 & 10 & 4 & 4 & 4 & 6 & 0,077 \\
5 & 5 & 5 & 5 & 5 & & 5 & 7 & 5 & 5 & 5 & 5 & 5 & 5 & 11 & 0,141 \\
6 & 1 & 2 & 3 & 6 & 5 & & 6 & 8 & 6 & 10 & 6 & 6 & 13 & 5 & 0,064 \\
7 & 1 & 2 & 7 & 7 & 7 & 6 & & 8 & 7 & 7 & 7 & 7 & 13 & 7 & 0,090 \\
8 & 1 & 2 & 8 & 8 & 5 & 8 & 8 & & 8 & 8 & 11 & 12 & 13 & 6 & 0,077 \\
9 & 1 & 2 & 3 & 4 & 5 & 6 & 7 & 8 & & 9 & 11 & 12 & 13 & 1 & 0,013 \\
10 & 1 & 2 & 3 & 10 & 5 & 10 & 7 & 8 & 9 & & 10 & 10 & 13 & 4 & 0,051 \\
11 & 1 & 11 & 3 & 4 & 5 & 6 & 7 & 11 & 11 & 10 & & 11 & 13 & 4 & 0,051 \\
12 & 12 & 2 & 12 & 4 & 5 & 6 & 7 & 12 & 12 & 10 & 11 & & 13 & 4 & 0,051 \\
13 & 1 & 2 & 13 & 4 & 5 & 13 & 13 & 13 & 13 & 13 & 13 & 13 & & 8 & 0,103 \\
\hline
\end{tabular}

Sumber: Hasil olah data.

Keterangan: *= nama butir 1-13 tercantum pada Tabel 2. 
Tabel 2. Matriks Evaluasi Faktor Internal (IFE)

\begin{tabular}{clccc}
\hline No & \multicolumn{1}{c}{ Faktor Strategis Internal } & Bobot & Peringkat & $\begin{array}{c}\text { Skor } \\
\text { Bobot }\end{array}$ \\
\hline & Kekuatan (strength) & & & \\
1 & Keunggulan distinctive budi daya dan pengolahan & 0,103 & 4 & 0,410 \\
2 & Tanaman kelapa tumbuh di pekarangan & 0,128 & 4 & 0,513 \\
3 & Memiliki dasar budi daya tanaman gula kelapa & 0,051 & 3 & 0,154 \\
4 & Memiliki dasar pengolahan gula kelapa & 0,077 & 3 & 0,231 \\
5 & Memiliki supply chain tradisional & 0,141 & 4 & 0,564 \\
6 & Kualitas SDM budi daya dan pengolahan relatif cukup & 0,064 & 2 & 0,128 \\
7 & Infrastruktur transportasi dan logistik cukup memadai & 0,051 & 2 & 0,103 \\
\hline & Kelemahan (weakness) & & & 0,090 \\
8 & Manajemen sangat sederhana & 0,090 & 1 & 0,154 \\
9 & Tidak ada pengendalian kualitas & 0,077 & 2 & 0,013 \\
10 & Teknologi sangat sederhana & 0,013 & 1 & 0,103 \\
11 & Tidak memiliki peralatan “dedicated” & 0,051 & 2 & 0,103 \\
12 & Produktifitas dan efisiensi rendah & 0,051 & 2 & 0,103 \\
\hline 13 & Takut bermitra dengan pihak lain & 0,103 & 1 & $\mathbf{2 , 6 6 7}$ \\
\hline
\end{tabular}

Sumber: Hasil olah data.

\section{Faktor Eksternal}

Ada beberapa faktor eksternal (peluang dan ancaman) yang mempengaruhi posisi daya saing Desa Sunyalangu sebagai desa inovatif dalam bidang budi daya dan produksi gula kelapa di Kabupaten Banyumas, yaitu:

\section{Peluang (Opportunity)}

\section{Diseminasi ilmu dan teknologi dari pihak luar}

Pada dasarnya teknologi budi daya dan teknologi proses sudah ada yang jauh lebih maju dengan apa yang dilakukan masyarakat Desa Sunyalangu, terutama dalam proses pembuatan gula kristal. Namun, link atau jaringan untuk mengakses hal tersebut masih sangat terbatas, ilmu pengetahuan dan teknologi yang dipakai di Desa Sunyalangu kurang berkembang. Kesadaran para stakeholders sangat diperlukan, yaitu para ilmuwan perguruan tinggi, pejabat pemerintah daerah dan pemerintah pusat, serta para eksportir atau pengusaha manufaktur sebagai mitra usaha di bidang pemrosesan gula kelapa untuk membantu mendiseminasi ilmu dan teknologi budi daya dan proses yang lebih maju. Diseminasi ini meliputi penyuluhan, pelatihan, dan alih teknologi melalui hibah.

\section{Proses sepanjang tahun}

Salah satu keunggulan utama yang ada di Desa Sunyalangu merupakan kesempatan UKM pemrosesan gula kelapa dan gula kristal untuk melakukan proses produksi sepanjang tahun. Kesempatan ini diperoleh karena banyaknya tanaman kelapa yang berada di pekarangan rumah masyarakat. Dengan banyaknya tanaman kelapa di pekarangan rumah, maka bahan baku akan tersedia secara terus menerus, baik saat 
musim kemarau maupun penghujan. Kondisi ini membedakan Desa Sunyalangu dengan daerah lain yang melakukan pemrrosesan hanya pada saat musim kemarau.

\section{Bantuan atau hibah pihak lain}

Tersedianya dana hibah pemerintah yang cukup banyak dan potensial untuk dimanfaatkan melalui program-program pendampingan desa maupun program lainnya. Banyak pula lembaga atau instansi yang memiliki dana lebih untuk membantu mengembangkan produk-produk ekspor unggulan desa.

\section{Ancaman (Threat)}

\section{Harga tidak menentu}

Harga produk sering tidak menentu tergantung hasil produksi. Jika produksi melimpah, maka harga akan cenderung murah. Sebaliknya, jika produksi sedang menurun, maka harga cenderung tinggi. Hal ini lebih disebabkan karena cuaca yang tidak menentu. Jika cuaca kemarau, maka nira yang dihasillkan akan lebih bagus.

\section{Beredarnya racun pemalsu dan kotor}

Dalam dunia perdagangan, banyak ide pedagang untuk mencari untung sebanyakbanyaknya melalui cara-cara yang tidak terpuji. Misalnya, penambahan larutan bahan kimia pada nira agar produk yang dihasilkan menjadi tidak murni organik. Selain itu, perilaku mencampur masakan gula dengan umbi-umbian agar hasil produksinya terlihat lebih banyak.

\section{Kapasitas produksi meningkat di tempat lain}

Di daerah lain, produksi gula kelapa dan gula kristal juga berkembang seperti yang terjadi di desa Sunyalangu. Kondisi inilah yang kadang membuat hasil produksi di tempat lain meningkat. Selain itu, kualitas nira yang dihasilkan dapat mempengaruhi kapasitas produksi yang dihasilkan.

\section{Ilmu dan teknologi yang sesuai}

Agar dapat berkembang dengan inovasinya, pihak lain yang memiliki fasilitas maupun kompetensi di bidang teknologi yang sesuai sangat diperlukan. Berdasarkan pengamatan, wawancara, dan analisis yang telah dilakukan, Desa Sunyalangu dapat berkembang menjadi desa inovatif melalui program pelatihan, penyuluhan, pendampingan, alih teknologi, dan bantuan sarana dan prasarana melalui:

\section{Peremajaan dan Perawatan Tanaman Kelapa}

Banyak tanaman kelapa yang sudah tua dan sudah tidak menghasilkan nira yang bagus, maka perlu dilakukannya perawatan dan juga penanaman kembali bibit Kelapa agar tanaman Kelapa tetap tumbuh.

2. Pengendalian mutu proses dan hasil produksi gula kelapa

Yang termasuk dalam kegiatan ini adalah: (a) Cara memeriksa adanya obat yang terkandung dalam nira, (b) Memeriksa kadar nira yang dihasilkan, (c) Cara menghilangkan obat yang sudah terlanjur ada dalam kandungan nira yang dihasilkan, dan (d) Cara mengatasi hasil produksi gula kelapa yang tidak sesuai dengan kriteria hasil produksi yang sesuai. 


\section{Proses yang baik dan benar}

Dalam kegiatan tersebut, masyarakat diberikan pelatihan dengan pendekatan GMP (good manufacturing practice) (Winarno \& Suyono, 2002: 317), yaitu: (a) Cara penyadapan air nira yang baik, (b) Menjaga agar nira yang dihasilkan dalam kualitas yang baik, (c) Memantau perapian saat memasak air nira agar tidak terjadi kebakaran, dan (d) Meningkatkan produktifitas dalam periode yang sama.

\section{Focus Group Discussion (FGD)}

Kegiatan FGD diselenggarakan di Balai Desa Sunyalangu Kecamatan Karanglewas pada bulan Juli 2018. FGD dimoderatori langsung oleh asisten peneliti dengan mengundang peserta multipihak sebanyak 10 orang yang terdiri atas: Sekretaris Desa Sunyalangu, Kepala Dusun I, Kepala Dusun II, tiga orang petani gula kelapa, seorang petani kopi, dua orang pengepul gula kelapa, dan seorang petani jagung.

Salah satu upaya untuk lebih mendorong perekonomian lokal adalah mendorong pengembangan tingkat desa dengan inovasi berbasis pada kearifan lokal, potensi sumber daya dan keunikannya. Desa-desa yang mampu mendayagunakan sumber dayanya dengan cara yang berbeda dikembangkan menjadi desa mandiri. Wacana untuk mengembangkan desa mandiri sudah ada di Kabupaten Banyumas, tetapi sejauh ini pemerintah kabupaten belum memutuskan desa mana di antara 301 desa yang akan dipilih untuk dikembangkan. Upaya pengembangan ini perlu difokuskan pada satu desa terlebih dahulu untuk nantinya dijadikan sebagai percontohan atau rujukan desa-desa lain yang akan bertransformasi menjadi desa mandiri.

Desa Sunyalangu termasuk di dalam wilayah Kecamatan Karanglewas Kabupaten Banyumas yang dapat ditempuh sekitar 90 menit dari Ibukota Kabupaten dengan jarak sekitar $15 \mathrm{~km}$. Dari kota Kecamatan Karanglewas berjarak kurang lebih $10 \mathrm{~km}$. Desa Sunyalangu berbatasan langsung dengan desa-desa lain yaitu, di sebelah utara ada hutan negara, sebelah barat Desa Sokawera Kecamatan Cilongok, sebelah selatan Desa Babakan Kecamatan Karanglewas, dan sebelah timur Desa Baseh Kecamatan Kedungbanteng. Hasil FGD menunjukkan adanya potensi kekayaan alam di Desa Sunyalangu, di antaranya potensi gula kelapa, padi, jagung, dan kopi. Hasil alam yang mendominasi adalah gula kelapa dengan banyaknya berdiri pengolahan gula kelapa di Desa Sunyalangu. Berdasarkan hasil FGD, beberapa faktor teridentifikasi dapat mempengaruhi posisi daya saing Desa Sunyalangu sebagai desa inovatif di bidang budi daya dan produksi gula kelapa, yaitu faktor internal (kekuatan dan kelemahan) dan faktor eksternal (peluang dan ancaman) sebagai berikut:

\section{Kekuatan (Strength)}

1.1 Keunggulan komparatif area budi daya dan pengolahan gula kelapa

Banyak area budi daya pohon kelapa di Desa Sunyalangu, yaitu masyarakat menanam pohon kelapa di pekarangan rumah maupun di kebun. Untuk pengolahannya, teknologi terbarukan yang dimiliki oleh beberapa pengepul di Desa Sunyalangu telah memiliki alat oven dengan teknologi terbarukan yang tidak dimiliki oleh desa lain. 
1.2 Memiliki pengetahuan dasar budi daya tanaman kelapa Anggota FGD yang sebagian besar petani gula kelapa telah memiliki pengetahuan tentang budi daya tanaman kelapa.

1.3 Memiliki pengetahuan dasar pengolahan gula cetak dan gula kristal Petani gula kelapa telah mempunyai alat pemasakan gula kelapa berupa tungku, wajan, alat penyaringan, serta alat pendukung lain untuk proses produksi gula cetak maupun gula kristal.

1.4 Kualitas SDM Budidaya dan Pengolahan Relatif Cukup

Petani dan pengepul gula kelapa di Desa Sunyalangu telah mendapatkan pelatihan dan kunjungan dari perusahaan swasta maupun pemerintah kabupaten yang ditujukan untuk meningkatkan kemampuan petani untuk menghasilkan gula kelapa dan gula kristal yang bernilai jual tinggi.

1.4 Infrastruktur transportasi cukup memadai

Desa Sunyalangu masuk dalam wilayah perbukitan dengan infrastruktur jalan yang cukup memadai. Kondisi ini memudahkan para pelaku usaha gula kelapa yang melakukan aktifitas, baik di dalam maupun di luar Desa Sunyalangu.

1.5 Memiliki sistem nilai rantai pasokan

Terbentuknya suatu mata rantai pasokan yang sederhana dimulai dari petani/ penderes gula kelapa, pengepul, dan eksportir.

\section{Kelemahan (Weakness)}

2.1 Manajemen sangat sederhana

Dalam menjalankan usaha, UKM gula semut masih menggunakan manajemen yang sederhana, belum ada perencanaan yang baik, dan belum ada pencatatan hasil usaha yang baik.

2.2 Tidak ada pengendalian kualitas

Tidak ada pengendalian kualitas secara maksimal, apalagi untuk proses gula semut yang memerlukan kualitas sangat baik untuk dapat diekspor, pengepul perlu melakukan proses lagi, seperti pengovenan gula semut agar kadar air sesuai dengan standar ekspor.

2.3 Teknologi pendukung sangat sederhana

Sebagian besar teknologi petani gula kelapa di Desa Sunyalangu masih menggunakan teknologi yang sederhana, seperti tungku, alat pengayak manual, dan lainlain.

2.4 Produktifitas dan efisiensi proses produksi rendah

Alat produksi pembuatan gula kelapa yang dimiliki Desa Sunyalangu masih mencapai produktifitas rendah. Dalam satu hari, hanya mampu melakukan satu kali proses produksi. Selain karena leadtime proses yang panjang, yaitu rata-rata 3-5 jam untuk gula cetak, dan 4-6 jam untuk gula kristal. Pengaturan untuk proses berikutnya belum ada. Bahkan, hasil produksi gula kelapa yang dihasilkan untuk dijual ke pengepul, biasanya menunggu hingga satu minggu terlebih dahulu baru kemudian dijual ke pengepul. Hal itu disebabkan proses produksi gula kristal yang memakan waktu cukup lama.

2.5 Takut Bermitra dengan pihak lain Sebagian peserta FGD mengaku bahwa para petani dan UKM gula kelapa takut bermitra dengan pihak lain, di antaranya karena ketakutan akan peraturan yang berbelit, pajak, dan lain-lain. 


\section{Peluang (Opportunity)}

3.1 Diseminasi ilmu dan teknologi dari pihak luar

Pada dasarnya teknologi budi daya dan teknologi proses sudah ada yang jauh lebih maju dengan apa yang dilakukan oleh masyarakat Desa Sunyalangu, terutama dalam proses pembuatan gula kristal. Namun, terbatasnya link atau jaringan untuk mengakses hal tersebut, ilmu pengetahuan, dan teknologi yang dipakai di Sunyalangu kurang berkembang.

3.2 Proses sepanjang tahun

Kesempatan UKM gula kelapa dan gula kristal melakukan proses sepanjang tahun. Kesempatan ini diperoleh karena banyaknya tanaman kelapa yang berada di pekarangan rumah. Dengan adanya tanaman kelapa yang berada di pekarangan rumah, maka bahan baku akan dihasilkan secara terus menerus baik saat kemarau maupun musim penghujan.

3.3 Bantuan atau hibah dari pihak lain

Peluang untuk mendapatkan hibah dari perusahaan swasta maupun pemerintah.

\section{Ancaman (Threat)}

\subsection{Harga tidak menentu}

Harga sering tidak menentu tergantung pada hasil produksi. Jika produksi melimpah, maka harga akan cenderung rendah, sedangkan jika produksi menurun harga akan cenderung meningkat. Hal tersebut juga disebabkan karena cuaca yang tidak menentu. Jika cuaca kemarau, maka nira yang dihasilkan akan bagus kualitasnya.

4.2 Beredarnya racun pemalsu dan kotor

Penambahan larutan bahan kimia pada nira akan menyebabkan kualitas yang dihasilkan menjadi tidak murni organik atau bahkan untuk hasil masakan gulanya sering dicampur dengan umbi-umbian agar terlihat lebih banyak hasil produksinya.

4.3 Kapasitas produksi meningkat di tempat lain

Di kecamatan lain di sekitar Desa Sunyalangu, produksi gula kelapa dan gula kristal juga sama berkembangnya. Hal tersebut kadang membuat hasil produksi di tempat lain meningkat. Selain itu, kualitas Nira yang dihasilkan dapat mempengaruhi kapasitas produksi yang dihasilkan.

Beberapa alternatif disusun untuk mengatasi berbagai kelemahan yang teridentifikasi, di antaranya adalah pada tahap ke-1 (fokus pada budi daya tanaman kelapa): (1) Peningkatan jumlah luasan tanaman kelapa, (2) Melakukan peremajaan tanaman kelapa, dan (3) Peningkatan kemampuan petani dalam cara bertani yang baik. Selanjutnya, alternatif pada tahap ke-2 (fokus pada proses pengolahan gula kelapa) adalah: (1) Pembenahan manajemen usaha, (2) Pembenahan kualitas produksi gula kelapa, (3) Diseminasi teknologi proses terbarukan, (4) Peningkatan produktifitas dan efisiensi produk gula kelapa, dan (5) Pendampingan memperoleh jaringan mitra dengan pihak lain.

\section{KESIMPULAN DAN SARAN}

\section{Kesimpulan}


Identifikasi sumber daya desa yang dapat membantu kemadirian ekonomi Desa Sunyalangu Kabupaten Banyumas adalah tanaman padi dan kelapa, tanaman pendukung lain adalah jagung dan kopi. Faktor kekuatan yang mendukung Desa Sunyalangu menjadi desa mandiri ekonomi di Kabupaten Banyumas adalah keunggulan komparatif yaitu memiliki: (1) area budi daya dan pengolahan gula kelapa, (2) tanaman kelapa yang banyak tumbuh di sekitar pekarangan, (3) dasar pembudidayaan tanaman kelapa, (4) dasar pengolahan gula cetak dan gula kristal, (5) kualitas sumber daya manusia untuk budi daya pengolahan, (6) infrastruktur transportasi cukup memadai, dan (7) sistem rantai pasok. Faktor kelemahan yang menghambat Desa Sunyalangu menjadi desa mandiri ekonomi di Kabupaten Banyumas adalah: (1) manajemen sangat sederhana, (2) tidak ada pengendalian kualitas, (3) teknologi pendukung sangat sederhana, (4) produktifitas dan efisiensi proses produksi masih rendah, dan (5) takut bermitra dengan pihak lain.

Kesempatan yang bisa dimanfaatkan Desa Sunyalangu menjadi desa mandiri ekonomi di Kabupaten Banyumas adalah: (1) diseminasi ilmu dan teknologi dari pihak luar (O1), (2) proses dilakukan sepanjang tahun, dan (3) bantuan atau hibah pihak lain. Di sisi lain, ancaman yang dapat mengganggu Desa Sunyalangu menjadi desa mandiri ekonomi di Kabupaten Banyumas adalah: (1) harga tidak menentu, (2) beredarnya racun pemalsu dan kotor, dan (3) kapasitas produksi meningkat di tempat lain.

\section{Saran}

Dari kesimpulan tersebut di atas, penulis menyarankan agar Desa Sunyalangu dapat diarahkan perkembangannya menjadi desa inovatif melalui program pelatihan, penyuluhan, pendampingan, dan alih teknologi berupa bantuan sarana dan prasarana.

\section{DAFTAR REFERENSI}

Chamber, R. (1996). Partisipatory Rural Appraisal: Memahami Desa Secara Partisipatif. Kanisius dan OXFAM.

David, R. F. (1997). Manajemen Strategi Konsep. Jakarta: Salemba Empat.

Becattini, G., Bellandi, M., Ottati, G. D., \& Sforzi, F. (2003) From Industrial Districts to Local Development. Edward Elgar Publishing, No 2884.

Henderson, W. (2007). Rural Urban Inequality in Asia. CAPSA Flash, Vol 5/9, September. UNESCAP-CPSA. Bogor.

IFPRI, ADB. (2007). Agricultural and Rural Development for Reducing Poverty in Asia: In Pussuit of Inclusive and Sustainable Growth. IFPRI. Washington D.C. USA and Manila: ADB.

Kurtz, D. L. (2008). Principle of Contemporary Marketing. Stamford: South-Western Educational Publishing, Inc.

Mubyarto. (1984). Strategi Pembangunan Perdesaan. Yogyakarta: P3PK UGM.

Oerlemans, L. A. G., Meeus, M. T. H., \& Boekema, F. W. M. (2001). Firm clustering and innovation: Determinants and effects. Papers in Regional Science, 80, 337356. doi:10.1111/j.1435- 5597.2001.tb01803.x.

Pearce, J. A. \& Robinson, R. B. (2013). Manajemen Strategis: Formulasi, Implementasi, dan Pengendalian. Jakarta: Salemba Empat. 
Bradford, R. W., Duncan, P., \& Tarcy, B. (2007). Simplified Strategic Planning: A Nonsense Guide for Busy People Who Want Result Fast. New York: McGrawHill International Edition.

Rochdyanto \& Saiful. (2000). Langkah-langkah Pelaksanaan Metode PRA. Makalah ToT PKPI. Yogyakarta.

Sajogyo (1982). Bunga Rampai Perekonomian Desa. Jakarta: Yayasan Obor Indonesia.

Sekretariat Negara. Undang-Undang Nomor 6 Tahun 2014 tentang Desa.

Timmer, C. P. (2006). The Structural Transformation in Historical Perspective: Lesson From Global Pattern and Divergent Country.

Thompson (2008). Crafting \& Executing Strategy: The Quest for Competitive Advantage. 17th ed. New York: McGraw-Hill International Edition. 